\title{
Misleading plasma electrolytes in diabetic children with severe hyperlipidaemia
}

\author{
BRIAN M FRIER, CHRISTOPHER R STEER, JOYCE D BAIRD, AND SUSAN BLOOMFIELD
}

Metabolic Unit, University Department of Medicine, and Medical Paediatric Unit, Western General Hospital, and Royal Hospital for Sick Children, Edinburgh

SUMMARY Severe abnormalities of plasma electrolyte concentrations were observed in 4 children who had massive hyperlipidaemia secondary to poorly-controlled, insulin-dependent diabetes mellitus. These electrolyte values were fallacious and invoked problems of clinical management, particularly with regard to fluid replazement. Each case is described and the interpretation of plasma electrolyte values in hyperlipidaemia is discussed.

Moderately raised serum lipids and lipoproteins often are found in adults with diabetes mellitus ${ }^{1-3}$ and in diabetic children ${ }^{4-6}$ both before and after treatment. Severe hyperlipidaemia in association with diabetes is however much less common. ${ }^{7}$ We describe 4 children with insulin-dependent diabetes who developed massive hyperlipidaemia associated with a variable degree of metabolic decompensation. In all 4 patients the plasma electrolyte values were fallaciously low.

\section{Case reports}

Case 1. An 11-year-old girl was admitted acutely ill, with a 3-month history of progressive weight loss, increased appetite, polydipsia, and polyuria. On examination she was pale, thin, clinically dehydrated, and had florid lipaemia retinalis. Her urine contained sugar, ketones, and protein. Blood glucose was moderately raised at $17 \cdot 1 \mathrm{mmol} / \mathrm{l}(308 \mathrm{mg} / 100 \mathrm{ml})$ and plasma electrolytes were abnormal with plasma sodium of $98 \mathrm{mmol} / 1$ (Table 1), arterial blood hydrogen ion concentration $\left[\mathrm{H}^{+}\right] 74 \mathrm{nmol} / 1 \mathrm{pH}$
$7 \cdot 13$ ), and bicarbonate $<6.0 \mathrm{mmol} / \mathrm{l}$. Her blood was lipaemic on inspection and severe hyperlipidaemia was confirmed biochemically (Table 1 ).

Shortly after admission she became drowsy with Kussmaul's respirations, and then she vomited. Intravenous fluids were started: $0.45 \%$ saline with potassium supplements, alternating with $5 \%$ dextrose. Soluble insulin was administered by continuous intravenous infusion at a rate of 3 units hourly, which was increased to 10 units hourly over 8 hours. Blood glucose remained unchanged during the first 12 hours of treatment, but the plasma electrolytes improved with the serum osmolality falling to $289 \mathrm{mmol} / \mathrm{kg}$, and the carbon dioxide $\left(\mathrm{CO}_{2}\right)$ content rising to $15.0 \mathrm{mmol} / \mathrm{l}$. The next day intravenous soluble insulin was replaced by monocomponent insulin, 6 units hourly by intramuscular injection, and $10 \mathrm{~g}$ carbohydrate drinks were given every 2 hours. After 48 hours blood glucose had returned to normal with normal arterial $\left[\mathrm{H}^{+}\right]$but the plasma $\mathrm{CO}_{2}$ content was still apparently low $(13 \cdot 5$ $\mathrm{mmol} / \mathrm{l})$. On day 5 a diet was started, which contained $170 \mathrm{~g}$ carbohydrate and $30 \mathrm{~g}$ fat (1700 calories).

Table 1 Initial blood biochemical estimations

\begin{tabular}{|c|c|c|c|c|c|c|c|c|c|c|c|c|}
\hline Case & $\begin{array}{l}\text { Blood } \\
\text { glucose } \\
(\text { mmol/l) }\end{array}$ & $\begin{array}{l}\text { Sodium } \\
(\mathrm{mmol} / \mathrm{l})\end{array}$ & $\begin{array}{l}\text { Potassium } \\
(\mathrm{mmol} / \mathrm{l})\end{array}$ & $\begin{array}{l}\text { Chloride } \\
(\text { mmol/l) }\end{array}$ & $\begin{array}{l}\mathrm{CO}_{2} \\
\text { content } \\
(\mathrm{mmol} / \mathrm{l})\end{array}$ & $\begin{array}{l}\text { Hydrogen } \\
\text { ion concen- } \\
\text { tration } \\
(\text { nmol/l) }\end{array}$ & $\begin{array}{l}\text { Urea } \\
(\text { mmol/l) }\end{array}$ & $\begin{array}{l}\text { Osmola- } \\
\text { lity } \\
(\mathrm{mmol} / \mathrm{kg})\end{array}$ & $\begin{array}{l}\text { Trigly- } \\
\text { cerides } \\
(\mathrm{mmol} / \mathrm{l})\end{array}$ & $\begin{array}{l}\text { Cholest- } \\
\text { erol } \\
(\mathrm{mmol} / \mathrm{l})\end{array}$ & $\begin{array}{l}\text { Phospho- } \\
\text { lipids } \\
\text { (mmol/l) }\end{array}$ & $\begin{array}{l}\text { Lipo- } \\
\text { protein } \\
\text { type* }\end{array}$ \\
\hline $\begin{array}{l}1 \\
2 \\
3 \\
4\end{array}$ & $\begin{array}{r}17 \cdot 1 \\
7 \cdot 0 \\
37 \cdot 0 \\
37 \cdot 2\end{array}$ & $\begin{array}{r}98 \\
125 \\
118 \\
86\end{array}$ & $\begin{array}{l}3 \cdot 5 \\
2 \cdot 9 \\
4 \cdot 8 \\
2 \cdot 7\end{array}$ & $\begin{array}{l}87 \\
95 \\
83 \\
63\end{array}$ & $\begin{array}{r}7 \cdot 5 \\
19 \cdot 0 \\
15 \cdot 0 \\
7 \cdot 8\end{array}$ & $\begin{array}{l}74 \\
50 \\
96\end{array}$ & $\begin{array}{l}1 \cdot 5 \\
3 \cdot 5 \\
5 \cdot 2 \\
3 \cdot 3\end{array}$ & $\begin{array}{l}327 \\
298 \\
318 \\
415\end{array}$ & $\begin{array}{r}172 \cdot 9 \\
55 \cdot 4 \\
112 \cdot 5 \\
223 \cdot 7\end{array}$ & $\begin{array}{l}26 \cdot 0 \\
22 \cdot 8 \\
20 \cdot 6 \\
41 \cdot 4\end{array}$ & $\begin{array}{c}10 \cdot 7 \\
14 \cdot 2 \\
- \\
-\end{array}$ & $\begin{array}{l}\mathbf{v} \\
\mathbf{v} \\
-\end{array}$ \\
\hline
\end{tabular}

Conversion: SI to traditional units-blood glucose: $1 \mathrm{mmol} / 1 \approx 18 \mathrm{mg} / 100 \mathrm{ml}$, urea: $1 \mathrm{mmol} / 1 \approx 6.0 \mathrm{mg} / 100 \mathrm{ml}, \mathrm{triglycerides}: 1 \mathrm{mmol} / 1 \approx 88 \cdot 5$ $\mathrm{mg} / 100 \mathrm{ml}$, cholesterol: $1 \mathrm{mmol} / 1 \approx 38.6 \mathrm{mg} / 100 \mathrm{ml}$, phospholipids: $1 \mathrm{mmol} / \mathrm{l} \approx 77.5 \mathrm{mg} / 100 \mathrm{ml}$.

* Beaumont et al.15 
An increase in dietary fat to $50 \mathrm{~g}$ daily induced a transient return of fasting chylomicronaemia (Fig. 1). The diabetes was stabilised on a diet providing 2000 calories $(240 \mathrm{~g}$ carbohydrate, $70 \mathrm{~g}$ fat, and $100 \mathrm{~g}$ protein) with twice-daily monocomponent insulin.

Plasma lipids declined steadily during treatment (Fig. 1) and were completely normal 3 weeks later.

Case 2. A 17-year-old girl with insulin-dependent diabetes for 5 years had persistent glycosuria and ketonuria for 2 weeks. Although continuing to take 20 units soluble insulin twice daily, she had neglected her treatment for 6 months and had lost $6 \mathrm{~kg}$ in weight by restricting her carbohydrate intake. On examination she was a moderately obese girl who did not appear acutely ill. There were no clinical signs of hyperlipidaemia. Blood glucose was $7 \cdot 0$ $\mathrm{mmol} / \mathrm{l}(126 \mathrm{mg} / 100 \mathrm{ml})$, the plasma $\mathrm{CO}_{2}$ content was moderately reduced at $19.0 \mathrm{mmol} / \mathrm{l}$, but the plasma electrolytes were abnormal with plasma sodium concentration of $125 \mathrm{mmol} / \mathrm{l}$ (Table 1). Her blood was grossly lipaemic on inspection and the serum lipids were greatly raised with fasting chylomicronaemia. She was treated with intramuscular soluble insulin 4 to 6 units hourly and drinks providing 10 to $20 \mathrm{~g}$ carbohydrate. This regimen was modified to provide less frequent insulin and oral carbohydrate, but was continued for 7 days. Ketonuria disappeared after 24 hours and

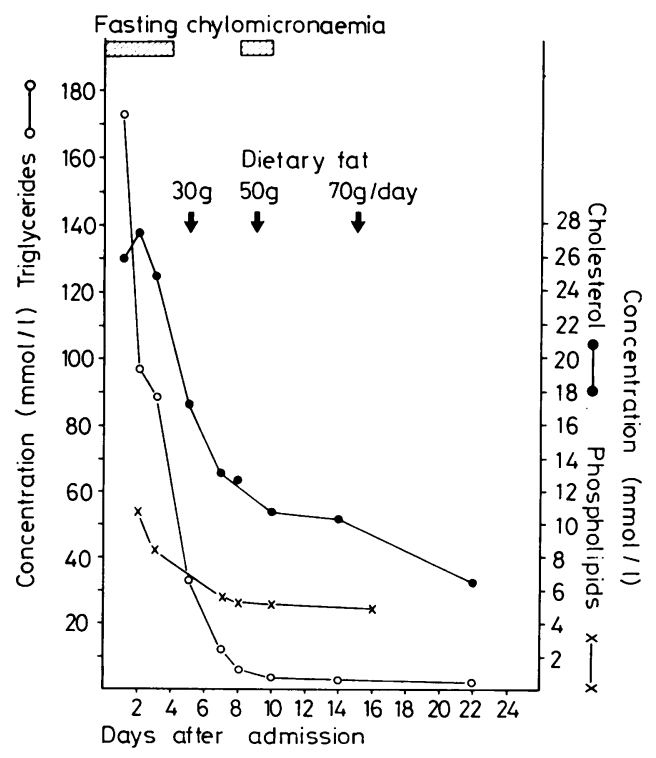

Fig. 1 (Case 1.) Serum lipid concentrations during treatment of diabetes. Introduction of dietary fat ( $g /$ day) is shown. the serum lipids continued to fall despite the reintroduction of dietary fat, although this produced fasting chylomicronaemia (Fig. 2). The diet contained $140 \mathrm{~g}$ carbohydrate, $50 \mathrm{~g}$ fat, and $63 \mathrm{~g}$ protein (1200 calories). Monocomponent insulin was begun twice daily. Post-heparin lipoprotein lipase activity ${ }^{8}$ measured at that time was normal, and 5 weeks after admission her fasting serum lipids were normal.

Case 3. A 9-year-old boy presented with polyuria, polydipsia, nocturnal enuresis, and weight loss of 2 weeks' duration. He was moderately dehydrated and had lipaemia retinalis. His blood was visibly lipaemic and he had glycosuria and ketonuria. Blood glucose was $37.0 \mathrm{mmol} / 1(665 \mathrm{mg} / 100 \mathrm{ml})$ and serum osmolality $318 \mathrm{mmol} / \mathrm{kg}$. Plasma electrolytes were abnormal (plasma sodium $118 \mathrm{mmol} / \mathrm{l}$ ) and serum lipids were raised (Table 1). Arterial $\left[\mathrm{H}^{+}\right]$was 50 $\mathrm{nmol} / \mathrm{l}(\mathrm{pH} 7 \cdot 32$ ), and bicarbonate $18.0 \mathrm{mmol} / \mathrm{l}$ with a base deficit of $8.0 \mathrm{mmol} / \mathrm{l}$. He was treated with soluble insulin by intravenous infusion (5 units $/ \mathrm{h}$ ) and $0.9 \%$ saline: $200 \mathrm{ml}$ an hour for 5 hours, then $100 \mathrm{ml}$ hourly with potassium supplements. Small amounts of oral fluids were tolerated from admission. Blood glucose fell to $16.0 \mathrm{mmol} / \mathrm{l}(288$ $\mathrm{mg} / 100 \mathrm{ml}$ ) in 18 hours. At that time serum bicarbonate was $20 \cdot 2 \mathrm{mmol} / \mathrm{l}$, serum osmolality 298 $\mathrm{mmol} / \mathrm{kg}$, and ketonuria had disappeared. A light diet without fat restriction was started on day 2 . Carbohydrate exchanges (10 g) were distributed throughout the day, giving a total of $200 \mathrm{~g}$ carbohydrate in 24 hours. Blood glucose was controlled with 6-hourly doses of subcutaneous soluble insulin, which was changed to a morning dose of isophane and soluble insulin on day $\lceil 3$. Lipaemia retinalis disappeared within 48 hours, but his plasma remained lipaemic for 5 days. After 11 days the

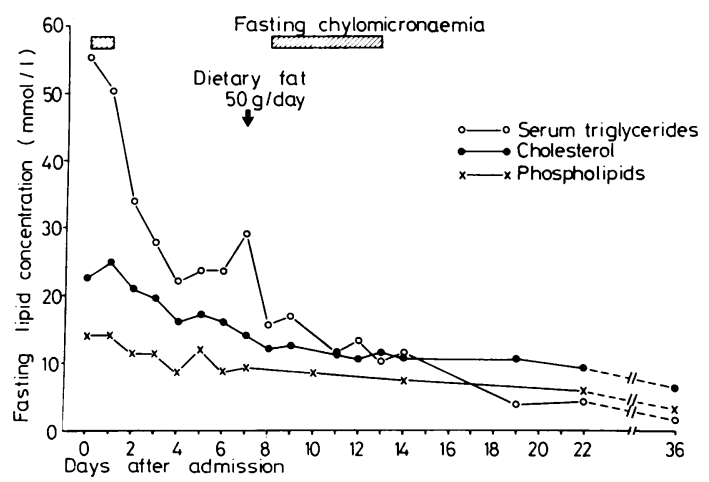

Fig. 2 (Case 2.) Serum lipid concentrations during treatment of diabetes, with dietary fat content ( $\mathrm{g} /$ day) shown. 
Table 2 (Case 4.) Serial plasma values

\begin{tabular}{|c|c|c|c|c|c|c|c|}
\hline \multicolumn{2}{|c|}{$\begin{array}{l}\text { Hours after } \\
\text { admission }\end{array}$} & \multirow{2}{*}{$\frac{\begin{array}{l}\text { Sodium } \\
(\mathrm{mmol} / \mathrm{l})\end{array}}{86}$} & \multirow{2}{*}{$\frac{\begin{array}{l}\text { Potassium } \\
(\mathrm{mmol} / \mathrm{l})\end{array}}{2 \cdot 7}$} & \multirow{2}{*}{$\begin{array}{c}\begin{array}{c}\text { Chloride } \\
(\mathrm{mmol} / \mathrm{l})\end{array} \\
63\end{array}$} & \multirow{2}{*}{$\begin{array}{l}\begin{array}{l}\text { Glucose } \\
(\mathrm{mmol} / \mathrm{l})\end{array} \\
37\end{array}$} & \multirow{2}{*}{$\begin{array}{l}\begin{array}{l}\text { Total } \mathrm{CO}_{2} \\
(\mathrm{mmol} / \mathrm{l})\end{array} \\
-\end{array}$} & \multirow{2}{*}{$\begin{array}{l}\begin{array}{l}\text { Osmolality } \\
(\mathrm{mmol} / \mathrm{kg})\end{array} \\
\begin{array}{l}415 \\
371\end{array}\end{array}$} \\
\hline $\begin{array}{l}0 \\
2\end{array}$ & Apparent & & & & & & \\
\hline 7 & $\begin{array}{l}\text { Apparent } \\
\text { Corrected* }\end{array}$ & $\begin{array}{l}116 \\
222\end{array}$ & $\begin{array}{l}2 \cdot 1 \\
3 \cdot 4\end{array}$ & $\begin{array}{r}88 \\
141\end{array}$ & $\begin{array}{r}6 \cdot 8 \\
10 \cdot 9\end{array}$ & $\begin{array}{l}11 \\
18\end{array}$ & $461 \dagger$ \\
\hline 12 & $\begin{array}{l}\text { Apparent } \\
\text { Corrected }\end{array}$ & $\begin{array}{r}113 \\
224\end{array}$ & $\begin{array}{l}2 \cdot 7 \\
4 \cdot 8\end{array}$ & $\begin{array}{r}92 \\
166\end{array}$ & $\begin{array}{r}6 \cdot 8 \\
12 \cdot 2\end{array}$ & - & $468 \dagger$ \\
\hline 21 & $\begin{array}{l}\text { Apparent } \\
\text { Corrected }\end{array}$ & $\begin{array}{l}122 \\
170\end{array}$ & $\begin{array}{l}3 \cdot 2 \\
4 \cdot 4\end{array}$ & $\begin{array}{r}84 \\
118\end{array}$ & $\begin{array}{l}24 \cdot 8 \\
34 \cdot 7\end{array}$ & $\begin{array}{l}12 \\
17\end{array}$ & $383+$ \\
\hline 25 & $\begin{array}{l}\text { Postexchange } \\
\text { (nonlipaemic serum) }\end{array}$ & 174 & $3 \cdot 4$ & 121 & $9 \cdot 1$ & 13 & 383 \\
\hline
\end{tabular}

* Corrected values obtained by lipid extraction with carbon tetrachloride and measuring plasma electrolyte concentrations in aqueous phase; other values calculated by correction using the factor obtained from: potassium in lipid-free extract/potassium in untreated serum.

tCalculated from the corrected plasma electrolyte values.

fasting serum cholesterol had fallen to $7.5 \mathrm{mmol} / \mathrm{l}$ $(290 \mathrm{mg} / 100 \mathrm{ml})$ and serum triglycerides to $3 \cdot 8$ $\mathrm{mmol} / \mathrm{l}(336 \mathrm{mg} / 100 \mathrm{ml})$, and by day 18 serum lipids were normal.

Case 4. A 6-year-old boy with insulin-dependent diabetes for 9 months had intermittent abdominal pain and vomiting for 2 weeks, culminating in progressive drowsiness and coma. On admission he was unconscious and dehydrated, with generalised hypotonia and lipaemia retinalis. His blood appeared strikingly lipaemic on inspection. The initial biochemical results are shown in Table 1; plasma sodium concentration was $86 \mathrm{mmol} / \mathrm{l}$. The serum amylase was normal. The significance of the abnormal electrolyte results in relation to the hyperlipidaemia was not recognised, and when the electrolyte results were reported 2 hours after admission, the intravenous fluid regimen was changed from $0.45 \%$ saline and sodium bicarbonate, to $0.9 \%$ saline. Soluble insulin ( $1 \mathrm{unit} / \mathrm{kg})$ was given hourly both by intravenous and intramuscular routes.

His conscious level remained unchanged, and 5 hours after admission he developed a right-sided hemiplegia. This did not respond to an intravenous infusion of dextran 40 . Tonic convulsions took place 11 hours after admission and papilloedema was observed. There was little response to treatment with dexamethasone and $20 \%$ mannitol, and the plasma electrolytes were still abnormal (Table 2), although blood glucose had fallen to $7 \cdot 1 \mathrm{mmol} / 1(128 \mathrm{mg} /$ $100 \mathrm{ml}$ ). There was a pronounced discrepancy between the apparent plasma electrolyte values and the osmolality. His clinical condition did not improve, so an exchange transfusion with heparinised blood was performed 21 hours after admission, over a period of 3 hours. This reduced blood viscosity and the degree of lipaemia, but serum lipids were not re-estimated. The lipaemia retinalis was much less

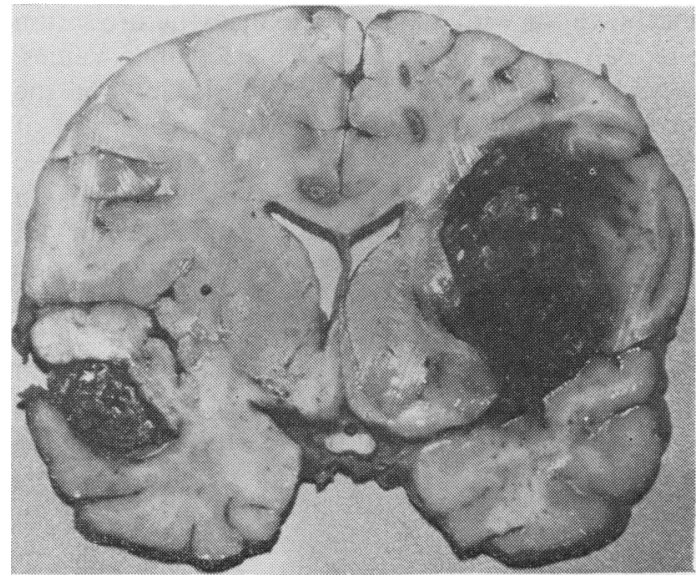

Fig. 3 (Case 4.) Appearance of brain at necropsy.

pronounced. Subsequent electrolyte estimations (Table 2) were now consistent with the serum osmolality of $383 \mathrm{mmol} / \mathrm{kg}$. The patient became decerebrate and died 33 hours after admission.

At necropsy the brain was swollen and necrotic, with extensive subarachnoid deposits of lipid and blood. The cerebral cortex had been disrupted by 2 large subarachnoid haematomata (Fig. 3). Many intracerebral vessels were occluded by a coagulum of blood and lipid, and were surrounded by a ring of interstitial haemorrhage. Histologically these vessels contained laminated red thrombus and lipid, and the neurones of the cerebral cortex showed acute ischaemic changes. Large amounts of lipid were present in the parenchymal cells of the liver, and the spleen contained numerous fat-laden macrophages.

\section{Discussion}

Severe hyperlipidaemia is a rare complication of poorly-controlled diabetes ${ }^{7-10}$ but early recognition 
is essential so that the standard treatment for diabetic ketoacidosis can be modified. Failure to appreciate the significance of the lipid abnormality can lead to misinterpretation of biochemical results and to the administration of inappropriate treatment. The presence of hyperlipidaemia of this magnitude should be recognised by the abnormal appearance of the blood at venepuncture and can be confirmed when the plasma is separated. Lipaemia retinalis, observed in 3 of our 4 patients, was the only relevant physical sign, and routine examination of the fundi should therefore be obligatory in all patients presenting with diabetic ketoacidosis.

The major problem in the immediate management of uncontrolled diabetes with severe hyperlipidaemia is the accurate measurement of plasma electrolyte concentrations with an inevitable delay before serum lipids can be estimated. Plasma electrolyte values, including bicarbonate, are spuriously low in the presence of hyperlipidaemia due to displacement of plasma water by lipid. ${ }^{911-12}$ Failure to recognise that the apparently severe hyponatraemia is an artefact may result in the administration of an excessive quantity of intravenous sodium chloride with the subsequent development of confusion and convulsions. ${ }^{13}$ Because of the delay in obtaining accurate electrolyte or lipid measurements in such cases, extreme caution must be exercised in replacing the extracellular fluid deficit with saline to reduce the risk of overloading with sodium. A recent report ${ }^{14}$ showed that even hypotonic saline in states of diabetic decompensation may exacerbate hypernatraemia. In Case 4, the extent of hypernatraemia was not evident until a significant amount of circulating lipid was removed by exchange transfusion.

A method for calculating the true electrolyte concentrations, based on the serum triglyceride concentration has been described. ${ }^{12}$ Alternatively, the lipids can be extracted from a plasma aliquot with carbon tetrachloride before measuring the electrolyte concentration in the aqueous phase (Table 2). Plasma osmolality is a useful guide to treatment, as it is unaffected by the presence of excess lipid ${ }^{9}$ and may demonstrate a discrepancy between plasma osmolality and electrolyte concentrations.

The severity of the acidosis does not correlate with the degree of hyperlipidaemia and may be relatively mild with only a moderate increase in blood glucose (Cases 1 and 2). Arterial hydrogen ion concentration $(\mathrm{pH})$ could be used in such cases to assess the degree of metabolic acidosis, since the estimated plasma bicarbonate or $\mathrm{CO}_{2}$ concentration is also misleading. Potassium replacement has to be empirical because of the difficulty of monitoring plasma potassium levels. In children, concurrent renal disease is unlikely and the risk of producing hyperkalaemia is small if the urinary output is satisfactory.

In such cases the insulin requirement may be much greater than 2 to 6 units hourly although this is generally adequate to treat diabetic ketoacidosis. The delayed biochemical improvement in Case 1 was caused by an inadequate amount of insulin being given for several hours after treatment was initiated. A fat-free diet eliminated any contribution of exogenous fat to the hyperlipidaemia; the reintroduction of fat to the diet of 2 patients (Cases 1 and 2) produced a return of fasting chylomicronaemia, and probably delayed the resolution of the hyperlipidaemia in Case 3.

The hyperlipidaemia was classified as type $V^{15}$ in the patients in whom lipoprotein electrophoresis was studied. None of these 4 patients had a family history of lipid disorder, and the fasting serum lipids were normal in all of the first-degree relatives of Cases 1, 2, and 4 (the relatives of Case 3 were not examined). This suggests that the hyperlipidaemia was secondary to the metabolic disturbance associated with the diabetes. Hyperlipidaemia of this magnitude seems to develop over a period of several weeks, or perhaps longer. Lipoprotein lipase activity is subnormal in association with insulin deficiency, ${ }^{7}$ and results in a decreased removal of circulatory lipid from the serum, ${ }^{16}$ but the mechanism by which this massive hyperlipidaemia is produced is not clear.

The degree of hyperlipidaemia was particularly severe in the child who died (Case 4). Severe hyperlipidaemia may predispose to increased platelet aggregation and blood hyperviscosity with thrombus formation, ${ }^{17-18}$ and these factors were probably responsible for the extensive intracerebral thrombosis found at necropsy. Theoretically, it might be supposed that heparin could be used to stimulate lipoprotein lipase activity, and help to prevent the consequences of the associated hypercoagulation state. However, by the time this degree of hyperlipidaemia has developed, the lipoprotein lipase enzyme system has probably been exhausted, and it is doubtful if administration of heparin would be of benefit.

Although this complication of uncontrolled diabetes is uncommon, inadequate or incorrect treatment can have serious consequences. It is important therefore that the fallacious plasma electrolyte values are not misinterpreted in massive diabetic hyperlipidaemia.

We thank Professor J W Farquhar and Dr A J Keay for permission to publish details of their patients, Professor Farquhar for advice, the laboratory staff 
of the Metabolic Unit, Western General Hospital, for serum lipid measurements, and Mr D Shirling for lipoprotein lipase estimations.

\section{References}

1 Wilson D E, Schreibman P H, Day V C, Arky R A. Hyperlipidaemia in an adult diabetic population. $J$ Chronic Dis 1970; 23: 501-6.

2 Hayes T M. Plasma lipoproteins in adult diabetes. Clin Endocrinol $(O x f) 1972 ; 1: 247-51$

3 Billimoria J D, Isaacs A J, Melki K. A lipid and lipoprotein profile of treated and untreated diabetics. Ann Clin Biochem 1976; 13: 315-21.

4 Sterky G, Larsson Y, Persson B. Blood lipids in diabetic and non-diabetic schoolchildren. Acta Paediatr Scand 1963; 52: 11-21.

5 Chance G W, Albutt E L, Edkins S M. Serum lipids and lipoproteins in untreated diabetic children. Lancet 1969; i: $1126-30$.

6 Chase H P, Glasgow A M. Juvenile diabetes mellitus and serum lipids and lipoprotein levels. Am J Dis Child 1976; 130: 1113-7.

7 Bagdade J D, Porte D, Jr, Bierman E L. Diabetic lipemia. $N$ Engl J Med 1967; 276: 427-33.

8 Fredrickson D S, Ono K, Davis L L. Lipolytic activity of postheparin plasma in hyperglyceridemia. J Lipid Res $1963 ; 4:$ 24-33.

9 Bell J A, Hilton P J, Walker G. Severe hyponatraemia in hyperlipaemic diabetic ketosis. Br Med J 1972; iv: 709-10.

10 Potter J L, Stone R T. Massive hyperlipidaemia in diabetic ketoacidosis. Clin Pediatr (Phila) 1975; 14: 412-3.

11 Albrink M J, Haid P M, Man E B, Peters J P. The displacement of serum water by the lipids of hyperlipemic serum. A new method for the rapid determination of serum water. J Clin Invest 1955 ; 34: 1483-8.

12 Steffes M W, Freier E F. A simple and precise method of determining true sodium, potassium, and chloride concentrations in hyperlipemia. J Lab Clin Med 1976; 88: 683-8.

13 Park B E, Meacham W F, Metsky M G. Nonketotic hyperglycemic hyperosmolar coma. Report of neurosurgical cases with a review of mechanisms and treatment. J Neurosurg 1976; 44: 409-17.

14 Daggett P, Deanfield J, Moss F, Reynolds D. Severe hypernatraemia in adults. $\mathrm{Br} \mathrm{Med} J 1979 ; \mathrm{i}: 1177-80$.

15 Beaumont J L, Carlson L A, Cooper G R, Feffar Z, Fredrickson D S, Strasser T. Classification of hyperlipidaemias and hyperlipoproteinaemias. Bull WHO 1970; 43: 891-915.

16 Fredrickson D S, Levy R I, Lees R S. Fat transport in lipoproteins-an integrated approach to mechanisms and disorders. Concluded. $N$ Engl J Med 1967; 276: 273-81.

17 Kwaan H C, Colwell J A, Suwanwela N. Disseminated intravascular coagulation in diabetes mellitus, with reference to the role of increased platelet aggregation. Diabetes 1972; 21: 108-13.

18 Timperley W R, Preston F E, Ward J D. Cerebral intravascular coagulation in diabetic ketoacidosis. Lancet 1974; i: 952-6.

Correspondence to Dr Brian M Frier, Metabolic Unit, University Department of Medicine, Western General Hospital, Edinburgh EH4 2XU.

Received 18 July 1979 